\title{
Antiplasmodial activity of Ethanolic extract of Cassia spectabilis DC leaf and its inhibition effect in Heme detoxification
}

\author{
Wiwied Ekasari ${ }^{1 *} \mathbb{D}$, Dewi Resty Basuki ${ }^{1}$, Heny Arwati $^{2}$ and Tutik Sri Wahyuni ${ }^{1}$
}

\begin{abstract}
Background: In previous studies, Cassia spectabilis DC leaf has shown a good antiplasmodial activity. Therefore, this study is a follow-up study of the extract of leaf of C. spectabilis DC on its in vitro and in vivo antiplasmodial activity and mechanism as an antimalarial.

Methods: The extract was fractionated, sub-fractionated and isolated to obtain the purified compound. In vitro antiplasmodial activity test against Plasmodium falciparum to find out the active compound. In vivo test against $P$. berghei ANKA-infected mice was conducted to determine prophylactic activity and antiplasmodial activity either alone or in combination with artesunate. The inhibition of heme detoxification test as one of the antimalarial mechanisms was carried out using the Basilico method.
\end{abstract}

Results: The results showed that active antimalarial compound isolated from C. spectabilis DC leaf had a structural pattern that was identical to (-)-7-hydroxycassine. Prophylactic test of $90 \%$ ethanolic extract of C. spectabilis DC leaf alone against $P$. berghei ANKA-infected mice obtained the highest percentage inhibition was $68.61 \%$, while positive control (doxycycline $13 \mathrm{mg} / \mathrm{kg}$ ) was $73.54 \%$. In combination with artesunate, $150 \mathrm{mg} / \mathrm{kg}$ three times a day of $C$. spectabilis $D C\left(D_{0}-D_{2}\right)+$ artesunate $\left(D_{2}\right)$ was better than the standard combination of amodiaquine + artesunate where the inhibition percentages were 99.18 and $92.88 \%$, respectively. The $I C_{50}$ of the extract for the inhibitory activity of heme detoxification was $0.375 \mathrm{mg} / \mathrm{ml}$ which was better than chloroquine diphosphate $(0.682 \mathrm{mg} / \mathrm{ml})$.

Conclusion: C. spectabilis DC leaf possessed potent antiplasmodial activity and may offer a potential agent for effective and affordable antimalarial phytomedicine.

Keywords: Cassia spectabilis DC, Combination, Heme detoxification, Plasmodium berghei, Plasmodium falciparum

\footnotetext{
* Correspondence: wiwied-e@ff.unair.ac.id; wiwiedeka@hotmail.com

'Department of Pharmacognosy and Phytochemistry, Faculty of Pharmacy, Universitas Airlangga, Campus C, Mulyorejo Street, Surabaya 60115, Indonesia

Full list of author information is available at the end of the article
} 


\section{Background}

Research to obtain new antimalarial drugs, both synthetic drugs and those derived from natural materials, especially from plants, is still ongoing. One of Indonesian plants that has been traditionally recognized to treat malaria is Cassia spectabilis DC from the Caesalpiniaceae family. Previous study related to this plant using in vivo test showed that this plant was a potential antimalarial phytomedicine [1]. New antimalarial active compounds have also been obtained from different plant, Cassia siamea from the same genus of C. spectabilis that identified as Cassiarin A alkaloid compound $[2,3]$. Based on these results, an in vitro test on antiplasmodial activity to find out the active compound isolated from $C$. spectabilis DC has been conducted.

Prevention of malaria can be done in various ways, one of which is chemoprophylaxis. Chemoprophylaxis is one way to reduce the risk of malaria infection and alleviate clinical symptoms of malaria. Chemoprophylaxis used before traveling to malaria endemic area to avoid infection. In Indonesia, therapeutic choice used for malaria prophylaxis is doxycycline and tetracycline [4]. Both can be used as chemoprophylaxis for malaria but there are many undesirable effects from this drug [5]. Therefore, this research was performed to find out and develop drugs that can be used as an effective antimalarial prophylaxis, safe, have few side effects, cheap, and easy to obtain, especially those from plants, namely C. spectabilis DC leaf.

Furthermore, antimalarial drug development and discovery is expected to provide new drugs which is not only have antiplasmodial activity in vitro and in vivo, but also has a safety mechanism to be applied to human. Research related to the biochemical process that unique of malaria parasites plays an important role in the development of new antimalarial drugs. Malaria parasites consume hemoglobin from erythrocytes during their life cycle, however, parasites are unable to digest ironcontaining heme molecule. Heme is toxic due to the reactivity of iron. Therefore, parasite has developed the mechanism to detoxify it by polymerization of heme to form hemozoin or malaria pigmen $[6,7]$. The structure of hemozoin through X-ray diffraction and IR spectroscopy has been found to be similar to $\beta$-hematin [8] $\beta$-hematin is synthetic hemozoin which chemically [8], spectroscopically [9] and crystallographically [10] similar to hemozoin which consists of Ferriprotoporphyrin units linked into a polymer by propionate oxygen-iron bonds [8, 11]. The inhibition of heme detoxification has been the target of antimalarial drugs, such as chloroquine and artemisinin $[12,13]$, since inhibit the heme detoxification can kill the parasites. Currently, the effect of ethanol extract of $C$. spectabilis DC leaf on biochemical activity such as potential inhibition of heme detoxification in the food vacuole of malaria parasite and stage- specific activity against asexual stage of parasite has been tested.

In addition, parasitic resistance to some of the existing antimalarial drugs is the biggest problem in overcoming this disease, especially in malaria endemic areas [14]. The combination therapy with artemisinin derivatives or commonly referred to artemisinin-based combination therapy (ACT) is highly recommended by WHO as the preferred therapy that is able to control the spread of resistance of $P$. falciparum $[15,16]$. Previous studies have found an effective dose of $90 \%$ ethanolic extract of $C$. spectabilis DC leaf was $150 \mathrm{mg} / \mathrm{kg}$ bodyweight which were given three times daily [1].

Based on this result, both ethanolic extract of $C$. spectabilis DC leaf alone and in combination with artesunate has been tested to determine the inhibition of growth of parasites in P. berghei ANKA-infected mice in vivo, since the ACT is more effective in reducing parasitemia [17]. The combination therapy will be carried out in extractdrug regimens and an overview of the resulting antimalarial activity will be obtained. A therapeutic effect of an appropriate combination of artesunate and 90\% ethanolic extract of C. spectabilis DC leaf is reported herein.

\section{Methods \\ Plant material}

C. spectabilis DC leaf was obtained from Purwodadi Botanical Garden-Indonesian Institute of Sciences [Lembaga Ilmu Pengetahuan Indonesia, LIPI], Pasuruan District, East Java Province, Indonesia, and the determination of specimen was performed at the above institution. The specimen was then deposited as herbarium in the Department of Pharmacognosy and Phytochemistry, Faculty of Pharmacy, Universitas Airlangga with registration number of $02 / \mathrm{W} / \mathrm{XI} / 2016$.

\section{Parasite and culture preparation}

Plasmodium falciparum 3D7 strain was obtained from Faculty of Pharmacy, Universitas Airlangga, Surabaya. The parasite was cultured in complete RPMI 1640 medium supplemented with $5.96 \mathrm{~g}$ HEPES, $0.05 \mathrm{~g}$ hypoxanthine, $2.1 \mathrm{~g} \mathrm{NaHCO}_{3}, 50 \mu \mathrm{g} / \mathrm{ml}$ gentamycin and completed with $10 \%$ human $\mathrm{O}+$ serum under anaerobe condition and incubated in a $37{ }^{\circ} \mathrm{C}$ incubator [18]. Parasitemia was observed daily prior to antimalarial assay. Plasmodium berghei ANKA strain was originally obtained from Eijkman Institute for Molecular Biology, Jakarta, and maintained at Faculty of Pharmacy, Universitas Airlangga. The P. berghei ANKA was infected into male BALB/c mice and observed the parasitemia level.

\section{Experimental animals}

Experimental animal used in this study was BALB/C strain male mice obtained from Faculty of Veterinary 
Medicine of Universitas Airlangga with a weight of \pm 20 $30 \mathrm{~g}$. Mice were acclimatized for 2 weeks at a temperature of $24 \pm 1{ }^{\circ} \mathrm{C}$ and humidity of $55 \pm 5 \%$ prior to in vivo test. In all in vivo experiments, the animals were kept in cages with raised, wide-mesh floors to prevent coprophagy. The ethical certificate was obtained from the Ethic Commission of Faculty of Veterinary Medicine of Universitas Airlangga No: 2.KE.181.10.2018. At the end of the tests, all animals were followed the euthanasia procedure. The mice were sacrificed by cervical dislocation after anesthesia by intraperitoneal injection of $100 \mathrm{mg} / \mathrm{kg}$ bodyweight ketamine [19]. The dead animals were then buried.

\section{Extraction}

The extract was made by three times macerating dried C. spectabilis DC leaf powder using $90 \%$ ethanol. The



Fig. 1 Flowchart of isolation steps of antiplasmodial alkaloid from C. spectabilis DC leaf 
macerated extract was then evaporated using a rotavapor.

Isolation of compound from C. spectabilis DC leaf A thousand grams of dried powder of C. spectabilis DC leaf was macerated with n-hexane, then the pulp powder was extracted again with methanol. The extract was subjected to liquid-liquid partition using ethyl acetate and $3 \%$ tartaric acid. The isolation proceess was done by adding 3\% tartaric acid until the atmosphere becomes acidic to turn the alkaloids in alkaline form into alkaloids salts. This alkaloid salt was partitioned using ethyl acetate, and the alkaloids were present in the aqueous acidic layer at the bottom. The alkaloid was the isolated from their salt form in aqueous layer, by adding $\mathrm{NaCO}_{3}$ to increase the $\mathrm{pH}$ to $9-10$, and the alkaloids returned to alkaline form. Furthermore, the aqueous layer with pH 9-10 was then extracted liquid-liquid using chloroform. The fractions so called chloroform fraction.

The isolate pure alkaloid compound from other compounds, the chloroform fraction, was further fractionationed by column chromatography using stationary phase of silica gel 60 with a series of gradient mobile phases was started using 100\% chlorofom, chloroform: ethyl acetate $\left(\mathrm{CHCl}_{3}\right.$ : EtOAc; 2:1), chloroform:ethyl acetate:methanol $\left(\mathrm{CHCl}_{3}\right.$ : EtOAc: $\left.\mathrm{MeOH} ; 2: 1: 2\right)$, and finally $100 \%$ methanol. The selection of the mobile phase was based on the results of the orientation by TLC, which gave good separation results. The solvent used for each gradient was $200 \mathrm{ml}$ and the collected fractions were combined based on similarity of the TLC profile. Nine fractions (C.1-C.9) were obtained.

The fractions were then assayed for their antiplasmodial activity. The active fraction was then subjected to silica gel 60 column chromatography and was eluted using $\mathrm{CHCl}_{3}: \mathrm{MeOH}(1: 00: 1)$ to yield sub-fractions (SFC.8.1-SFC.8.4). The sub-fractions were further assayed for their antiplasmodial activity. The antimalarial active sub-fraction was then purified by preparative thinlayer chromatography (PTLC) using $\mathrm{CHCl}_{3}: \mathrm{MeOH}$ (8.5: 1.5) to yield compounds C.8.3.1 and C.8.3.2. Identification of active compound was carried out using the TLCdensitometry, UV-Vis spectrophotometry, FTIR spectroscopy, and NMR. The procedures employed for the preparation of the plant active compounds are illustrated in Fig. 1.

\section{In vitro antiplasmodial activity test}

The extract was dissolved in DMSO (the final DMSO concentration in a well culture plate not more than $0.5 \%)$ and diluted with complete RPMI medium containing RPMI 1640, 10\% human plasma, $25 \mathrm{mM}$ HEPES, and $25 \mathrm{mM} \mathrm{NaHCO}_{3}$ to make the final concentrations of 10 , $1,0.1,0.01$, and $0.001 \mu \mathrm{g} / \mathrm{ml}$. Stock of parasite cultures were further diluted with uninfected type $\mathrm{O}+$ human erythrocytes and culture medium to make initial parasitemia of $1 \%$ and a hematocrit of $2 \%$. This final parasite culture was immediately used for antiplasmodial assay. The test was carried out in duplicate. The plates containing parasite cultures and extracts were then incubated in a $37^{\circ} \mathrm{C}$ incubator in a candle jar for $48 \mathrm{~h}$. Observation of stage-specific antiplasmodial activity in this in vitro test was performed by sampling the blood films from each well at $6,12,24$, and $48 \mathrm{~h}$. At the end of test thin films were prepared from each well and stained with $10 \%$ Giemsa solution prior to counting parasitemia [20]. The $50 \%$ inhibitory concentration $\left(\mathrm{IC}_{50}\right)$ value was determined using probit analysis based on the relation of log concentration of test compound and \% inhibition of parasites growth.

\section{In vivo antimalarial prophylactic activity test}

In vivo test for antimalarial prophylactic activity of $90 \%$ ethanolic extract of C. spectabilis DC leaf used Peters method with slight modification [21]. Forty two male adult $\mathrm{BALB} / \mathrm{c}$ mice were randomly divided into six groups [22]. Group 1 as a negative control group was given a $0.5 \% \mathrm{Na} C M C$ suspension solution. Groups 2, 3, 4 , and 5 were given extract at the doses of 100, 200, 400, and $800 \mathrm{mg} / \mathrm{kg}$, respectively. Group 6 as a positive control group was given a doxycycline of $13 \mathrm{mg} / \mathrm{kg}$ suspension solution. Each treatment was given orally once a day for 4 days before parasite infection. On the fourth day the mice were infected with $P$. berghei ANKA. Each mouse in each group was infected with $1 \times 10^{6}$ infected erythrocytes. Thin blood films from each mouse were made at $72 \mathrm{~h}$ post infection. Determination of parasitemia, percentage of the parasites' growth, percentage

Table 1 The percentage growth inhibition of P. falciparum 3D7 by extract and fractions of C. spectabillis DC leaf

\begin{tabular}{|c|c|c|c|c|c|c|c|}
\hline \multirow[t]{2}{*}{ Extract/faction } & \multirow{2}{*}{$\begin{array}{l}\text { Weight } \\
\text { (g) }\end{array}$} & \multicolumn{5}{|c|}{ Concentration $(\mu \mathrm{g} / \mathrm{ml})$} & \multirow{2}{*}{$\begin{array}{l}\mathrm{IC}_{50} \\
(\mu \mathrm{g} / \\
\mathrm{ml})\end{array}$} \\
\hline & & 100 & 10 & 1 & 0.1 & 0.01 & \\
\hline Hexane extract & 118.34 & 0 & 0 & 0 & 0 & 0 & ND \\
\hline Methanolic extract & 141.68 & 100 & $68.67 \pm 5.19$ & $14.36 \pm 2.26$ & 0 & 0 & 1.10 \\
\hline Ethyl acetate fraction & 100.21 & 100 & $96.56 \pm 4.86$ & $75.47 \pm 3.38$ & $16.41 \pm 3.78$ & 0 & 0.41 \\
\hline Chloroform fraction & 4.06 & 100 & $79.80 \pm 1.87$ & $56.36 \pm 12.12$ & $31.38 \pm 12.58$ & 0 & 0.55 \\
\hline
\end{tabular}


Table 2 The percentage growth inhibition of P. falciparum 3D7 by chloroform fractions of C. spectabillis DC leaf

\begin{tabular}{|c|c|c|c|c|c|c|c|}
\hline \multirow{2}{*}{\multicolumn{2}{|c|}{$\begin{array}{l}\text { Weight of } \\
\text { fraction (mg) }\end{array}$}} & \multicolumn{5}{|c|}{ Concentration $(\mu \mathrm{g} / \mathrm{ml})$} & \multirow{3}{*}{$\begin{array}{l}\begin{array}{l}\mathrm{I} \mathrm{C}_{50} \\
(\mu \mathrm{g} / \mathrm{ml})\end{array} \\
>>10\end{array}$} \\
\hline & & \multirow{2}{*}{$\begin{array}{l}10 \\
27.97 \pm 5.46\end{array}$} & \multirow{2}{*}{$\begin{array}{l}1 \\
0\end{array}$} & \multirow{2}{*}{$\begin{array}{l}0.1 \\
0\end{array}$} & \multirow{2}{*}{$\begin{array}{l}0.01 \\
0\end{array}$} & \multirow{2}{*}{$\begin{array}{l}\mathbf{0 . 0 0 1} \\
0\end{array}$} & \\
\hline C.1 & 20.00 & & & & & & \\
\hline C.2 & 4.10 & 0 & 0 & 0 & 0 & 0 & ND \\
\hline C.3 & 13.90 & $31.82 \pm 3.51$ & $6.39 \pm 3.95$ & 0 & 0 & 0 & $>10$ \\
\hline C. 4 & 17.90 & $93.07 \pm 6.36$ & $59.02 \pm 1.38$ & $28.22 \pm 8.39$ & $10.54 \pm 9.24$ & 0 & 0.384 \\
\hline C.5 & 7.70 & 100 & $62.74 \pm 6.03$ & $24.03 \pm 1.19$ & 0 & 0 & $1-0.1$ \\
\hline C.6 & 104.40 & $97.40 \pm 3.67$ & $93.50 \pm 6.81$ & $65.50 \pm 18.95$ & $14.92 \pm 7.44$ & 0 & 0.060 \\
\hline C.7 & 94.20 & $91.90 \pm 1.23$ & $84.84 \pm 2.91$ & $68.22 \pm 4.91$ & $48.83 \pm 11.03$ & 0 & 0.011 \\
\hline C.8 & 366.10 & 100 & 100 & $84.39 \pm 7.54$ & $66.26 \pm 3.58$ & $42.90 \pm 4.50$ & 0.002 \\
\hline C.9 & 36.50 & 100 & $87.36 \pm 6.41$ & $65.51 \pm 3.78$ & $58.52 \pm 1.33$ & $37.96 \pm 15.12$ & 0.005 \\
\hline
\end{tabular}

ND Not Detected

inhibition of parasites' growth, and effective dose 50 $\left(\mathrm{ED}_{50}\right)$ were based on Ekasari et al. [20].

\section{Suppressive effect of ethanolic extract of C. spectabilis DC leaf combined with artesunate}

The purpose of this test was to increase the effectiveness of the extract. The suppressive effect of ethanolic extract of C. spectabilis DC leaf in combination with artesunate, respectively against $P$. berghei ANKA infection in mice was determined using Peters' 4-day suppression test procedure [21]. A donor mouse densely infected with parasites was anaesthetized with chloroform and the blood was collected through cardiac puncture. The presence of parasitemia was established by microscopic examination of a thin blood film. The blood was diluted with phosphate buffered saline (PBS) so that each $0.2 \mathrm{ml}$ of blood contained $1 \times 10^{6} P$. berghei ANKA infected with erythrocytes. A total of $0.2 \mathrm{ml}$ of diluted blood was injected intraperitoneally into 36 healthy mice. The infected animals were randomly divided into six groups those were Group A-F. The animals were treated shortly after inoculation on day zero $\left(\mathrm{D}_{0}\right)$. Group $\mathrm{A}$ was given artesunate at $36.4 \mathrm{mg} / \mathrm{kg}$, on $\mathrm{D}_{0}-\mathrm{D}_{2}$. Group $\mathrm{B}$ was given ethanolic extract of C. spectabilis DC leaf at $150 \mathrm{mg} / \mathrm{kg}$ (three times a day) concurrently with artesunate at 36.4 $\mathrm{mg} / \mathrm{kg}$ (once a day), on $\mathrm{D}_{0}-\mathrm{D}_{2}$. Group $\mathrm{C}$ was given ethanolic extract of C. spectabilis DC leaf at $150 \mathrm{mg} / \mathrm{kg}$ (three times a day) on $\mathrm{D}_{0}-\mathrm{D}_{2}$ and artesunate at $36.4 \mathrm{mg} /$ $\mathrm{kg}$ (once a day), on $\mathrm{D}_{0}$. Group $\mathrm{D}$ was given ethanolic extract of C. spectabilis DC leaf at $150 \mathrm{mg} / \mathrm{kg}$ (three times a day) on $\mathrm{D}_{0}-\mathrm{D}_{2}$ and artesunate at $36.4 \mathrm{mg} / \mathrm{kg}$ (once a day), on $\mathrm{D}_{2}$. Group $\mathrm{E}$ was given amodiaquine at $72.8 \mathrm{mg} /$ $\mathrm{kg}$ concurrently with artesunate at $36.4 \mathrm{mg} / \mathrm{kg}$, once a day, on $\mathrm{D}_{0}-\mathrm{D}_{2}$. Group $\mathrm{F}$ received $0.2 \mathrm{ml}$ of $0.5 \% \mathrm{Na}$ CMC solution as control group. Oral route was used for all administration. On day three $\left(D_{3}\right)$, thin film was made from each mouse-tail blood stained with Giemsa. Determination of parasitemia level, percentage parasites' growth, percentage inhibition of parasites' growth, and the $\mathrm{ED}_{50}$ were as described on Ekasari et al. [20].

\section{Heme polymerization inhibition test}

The inhibition of heme polymerization test was performed based on the Basilico method [23] with slight modification in the concentration of hematin solution and the sample used. The Basilico method is an in vitro spectrophotometric microassay of heme polymerization. A 96-well Ubottomed microplates was used in this assay. The relative amounts of polymerized and unpolymerized hematin were determined using an ELISA reader. The final concentration of the extract samples ranged from 2 to $0.01 \mathrm{mg} / \mathrm{ml}$.

Table 3 The percentage growth inhibition of P. falciparum 3D7 by sub-fractions of C. spectabillis DC leaf

\begin{tabular}{|c|c|c|c|c|c|c|c|}
\hline \multirow{2}{*}{$\begin{array}{l}\text { Sub- } \\
\text { faction }\end{array}$} & \multirow{2}{*}{$\begin{array}{l}\text { Weight } \\
\text { (mg) }\end{array}$} & \multicolumn{5}{|c|}{ Concentration $(\mu \mathrm{g} / \mathrm{ml})$} & \multirow{2}{*}{$\begin{array}{l}\mathrm{IC}_{50} \\
(\mu \mathrm{g} / \mathrm{ml})\end{array}$} \\
\hline & & 10 & 1 & 0.1 & 0.01 & 0.001 & \\
\hline SFC.8.1 & 8.65 & $99.56 \pm 0.59$ & $86.42 \pm 3.19$ & $70.95 \pm 0.17$ & $62.71 \pm 3.82$ & $53.30 \pm 4.67$ & 0.001 \\
\hline SFC.8.2 & 11.25 & 0 & 0 & 0 & 0 & 0 & 0 \\
\hline SFC.8.3 & 32.50 & 100 & $72.84 \pm 6.81$ & $62.58 \pm 6.01$ & $46.59 \pm 0.47$ & $31.08 \pm 7.40$ & 0.016 \\
\hline SFC.8.4 & 20.50 & $76.74 \pm 16.36$ & 0 & 0 & 0 & 0 & $>1$ \\
\hline
\end{tabular}


Table 4 The percentage growth inhibition of P. falciparum 3D7 by compounds C.8.3.1 and C.8.3.2 of C. spectabillis DC leaf

\begin{tabular}{|c|c|c|c|c|c|c|c|}
\hline \multirow[t]{2}{*}{ Compound } & \multirow{2}{*}{$\begin{array}{l}\text { Weight } \\
\text { (mg) }\end{array}$} & \multicolumn{5}{|c|}{ Concentration $(\mu \mathrm{g} / \mathrm{ml})$} & \multirow{2}{*}{$\begin{array}{l}I C_{50} \\
(\mu \mathrm{g} / \\
\mathrm{ml})\end{array}$} \\
\hline & & 10 & 1 & 0.1 & 0.01 & 0.001 & \\
\hline C.8.3.1 & 4.30 & $97.23 \pm 1.49$ & $80.11 \pm 0.69$ & $67.61 \pm 1.93$ & $46.77 \pm 0.91$ & $27.71 \pm 1.35$ & 0.016 \\
\hline C.8.3.2 & 2.60 & 100 & $77.21 \pm 2.81$ & $50.56 \pm 10.48$ & $31.96 \pm 13.61$ & 0 & 0.070 \\
\hline
\end{tabular}

A $100 \mu \mathrm{l}$ of $1 \mathrm{mM}$ hematin solution was mixed with 0.2 $\mathrm{M} \mathrm{NaOH}$ and $50 \mu \mathrm{l}$ of the test extract. A $50 \mu \mathrm{l}$ of glacial acetic acid solution ( $\mathrm{pH} 2.6)$ was then added to this mixture. This test was carried out at $37^{\circ} \mathrm{C}$ for $24 \mathrm{~h}$. The microtube was then centrifuged at $8000 \mathrm{rpm}$ for $10 \mathrm{~min}$, the sediment was then washed with $200 \mu$ l of DMSO three times at $8000 \mathrm{rpm}$ for $10 \mathrm{~min}$. The $\beta$-hematin crystalline precipitated was dissolved in $200 \mu \mathrm{l}$ of $\mathrm{NaOH} 0.1 \mathrm{M}$ to form alkaline hematin. A $100 \mu \mathrm{l}$ of the alkaline hematin solution was transferred to 96-well microplates and the absorbance was read by ELISA reader at a wavelength of $405 \mathrm{~nm}$. The effects of each test substance on $\beta$-hematin production were calculated and compared with negative controls.

\section{Results}

\section{In vitro antiplasmodial activity test}

All the extracts, fractions, sub-fractions, and isolated compounds from C. spectabilis DC leaf were continuously screened in vitro for their antiplasmodial activity against chloroquine-sensitive P. falciparum (3D7 strain), using microtechnique which demonstrated on the previous study [24]. The samples for these tests were hexane extract, methanolic extract, ethyl acetate fraction and chloroform fraction. The results are shown in Table 1. Antiplasmodial activity was classified based on the Gessler et al. [25], where antiplasmodial activity of extract was considered very good, moderate, and low with $\mathrm{IC}_{50}$ value less than $10 \mu \mathrm{g} / \mathrm{ml}, 10$ to $50 \mu \mathrm{g} / \mathrm{ml}$, and more than $50 \mu \mathrm{g} / \mathrm{ml}$, respectively.

During isolation of compound, chloroform was used to fractionate the extract. Chloroform fractionation resulted in nine fractions called C.1-C.9. In vitro antiplasmodial activity test of these fractions showed that fraction C.8 was the most active fraction with $\mathrm{IC}_{50}$ was $0.02 \mu \mathrm{g} / \mathrm{ml}$ (Table 2). Purification of fraction C.8 resulted in four sub-fractions called SFC.8.1-SFC.8.4, and their antiplasmodial activity is shown in Table 3. Sub-fraction SFC.8.1 and SFC.8.3 showed antiplasmodial activity against $P$. falciparum 3D7 strain with $\mathrm{IC}_{50} 0.012$ and $0.015 \mu \mathrm{g} / \mathrm{ml}$, respectively. The purification of subfractions SFC.8.3 resulted in two compounds called compound C.8.3.1 and C.8.3.2 and their antiplasmodial activity is shown in Table 4 and Fig. 2. Compound C.8.3.1 and C.8.3.2 showed antiplasmodial activity against $P$. falciparum 3D7 strain with $\mathrm{IC}_{50} 0.016$ and $0.070 \mu \mathrm{g} / \mathrm{ml}$, respectively.
Identification using TLC-densitometry showed that compound C.8.3.1 was in the range of $\lambda 200-300 \mathrm{~nm}$, with a value of $R_{\mathrm{F}}=0.65$. Identification using FTIR spectroscopy showed an absorption peak at $472.53 \mathrm{~cm}^{-1}$; $657.68 \mathrm{~cm}^{-1} ; \quad 786.9 \mathrm{~cm}^{-1} ; \quad 864.05 \mathrm{~cm}^{-1} ; 1101.28 \mathrm{~cm}^{-1}$; $1382.87 \mathrm{~cm}^{-1}$ (Fig. 3).

Identification using ${ }^{1} \mathrm{H}-\mathrm{NMR}$ spectroscopy showed a characteristic signal of two hydroxyl protons at $\delta 3.60$ $\operatorname{ppm}(1 \mathrm{H}, \mathrm{s})$; and $\delta 3.69 \mathrm{ppm}(1 \mathrm{H}, \mathrm{s})$, two protons from the $\mathrm{CH}_{2}$ group of benzene at $\delta 1.91 \mathrm{ppm}(2 \mathrm{H}, \mathrm{s}, \mathrm{H}-4)$ and $\delta 1.68 \mathrm{ppm}(2 \mathrm{H}, \mathrm{s}, \mathrm{H}-5)$, one methyl group at $\delta 2.13$ ppm $\left(3 \mathrm{H}, \mathrm{s}, \mathrm{H}-12^{\prime}\right)$, and some cassettes of the $\mathrm{CH}_{2}$ groups of the aliphatic chain at $\delta 1.38 \mathrm{ppm}\left(2 \mathrm{H}, \mathrm{s}, \mathrm{H}-1^{\prime}\right)$; at $\delta 1.22 \mathrm{ppm}\left(2 \mathrm{H}, \mathrm{s}, \mathrm{H}-2^{\prime}-\mathrm{H}-8^{\prime}\right)$; at $\delta 1.51 \mathrm{ppm}(2 \mathrm{H}, \mathrm{s}$, $\left.\mathrm{H}-9^{\prime}\right)$, and at $\delta 2.35 \mathrm{ppm}\left(2 \mathrm{H}, \mathrm{t}, \mathrm{H}-10^{\prime}\right)$. Identification using ${ }^{13} \mathrm{C}$-NMR spectroscopy showed the presence of one carbon with a ketone group at $\delta 179.0 \mathrm{ppm}$, carbon in the benzene group at $\delta 56.96 \mathrm{ppm} ; \delta 67.13 \mathrm{ppm} ; \delta$ $29.23 \mathrm{ppm} ; \delta 25.77 \mathrm{ppm}$; and $\delta 48.29 \mathrm{ppm}$, carbon in the aliphatic chain at $\delta 34.32 \mathrm{ppm} ; \delta 25.87 \mathrm{ppm} ; \delta 29.23$ ppm; $\delta 29.33 \mathrm{ppm} ; \delta 22.89 \mathrm{ppm}$; and $\delta 38.87 \mathrm{ppm}$, one carbon in the methyl group at $\delta 30.23 \mathrm{ppm}$, and one carbon in the hydroxyl group at $\delta 65.27 \mathrm{ppm}$.

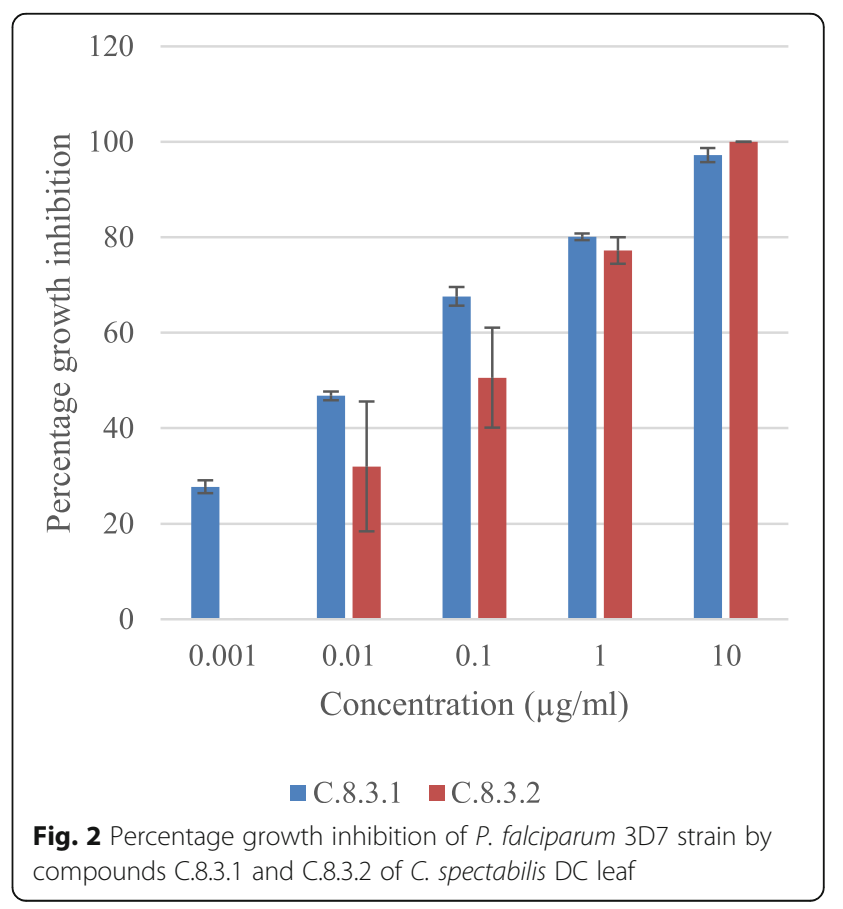




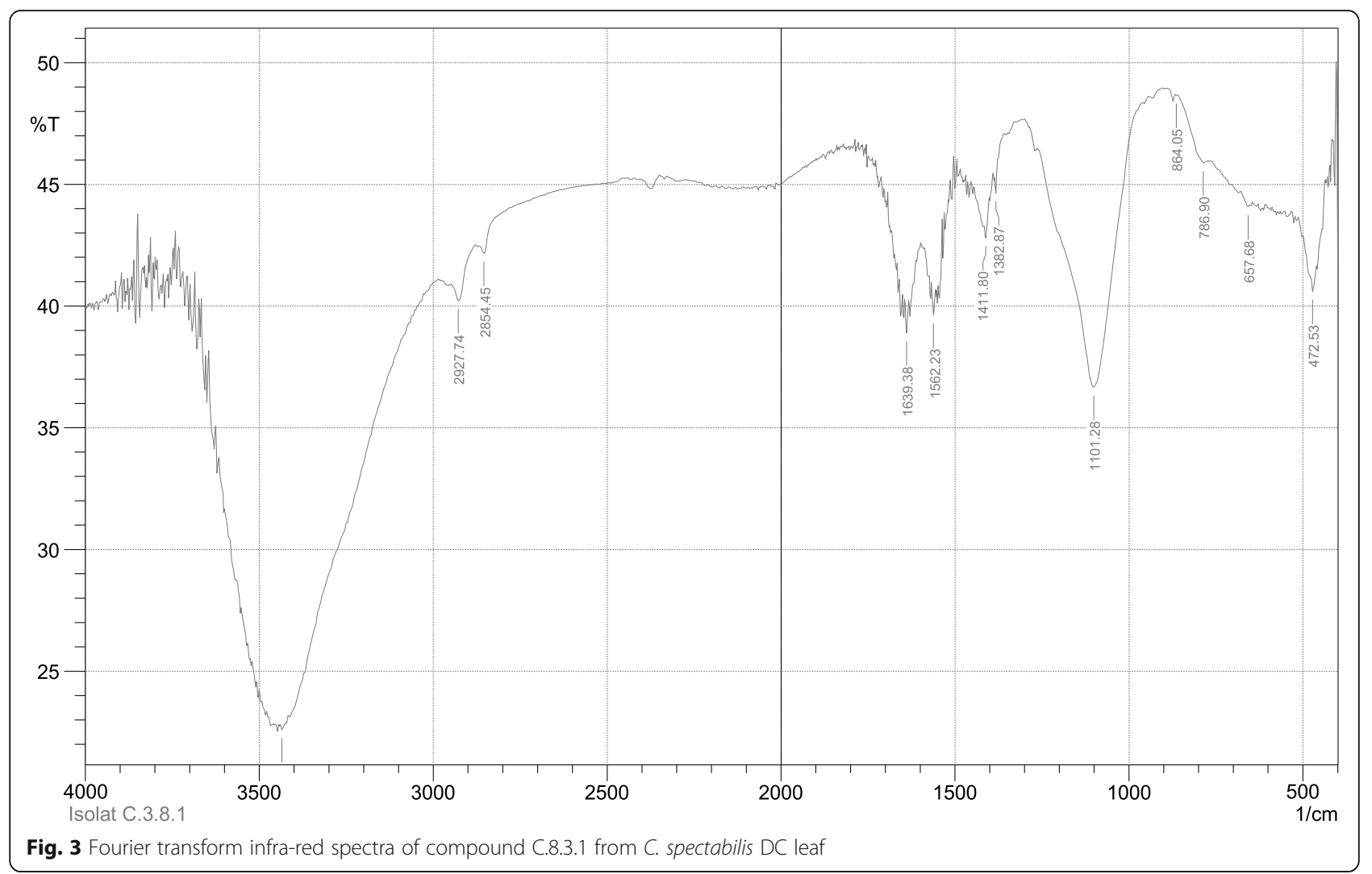

\section{Effect of $C$. spectabilis on parasitic stage development}

Stage-specific activity test of $90 \%$ ethanolic extract of $C$. spectabilis DC leaf against $P$. falciparum 3D7 strain was performed at different incubation periods of $0,6,12,24$, and $48 \mathrm{~h}$ to find out the effect of the extract to the growth of parasites at each stage of development. The extract concentration used was $100 \mu \mathrm{g} / \mathrm{ml}$. The results of this experiment are shown in Table 5 and Fig. 4.

No sharp difference was observed on the growth of each parasitic stage during incubation period of $0-12 \mathrm{~h}$. However, opposite direction of percentage parasitemia was seen at 12 to $48 \mathrm{~h}$ post incubation compared with

Table 5 Stage-specific activity of 90\% ethanolic extracts of C. spectabilis DC leaf against $P$. falciparum 3D7 strain

\begin{tabular}{|c|c|c|c|c|c|c|c|}
\hline \multirow[t]{2}{*}{ Samples } & \multirow{2}{*}{$\begin{array}{l}\text { Incubation } \\
\text { time } \\
\text { (hours) }\end{array}$} & \multicolumn{3}{|c|}{ Parasitic stage } & \multirow{2}{*}{$\begin{array}{l}\% \\
\text { parasitemia }\end{array}$} & \multirow{2}{*}{$\begin{array}{l}\% \\
\text { growth }\end{array}$} & \multirow{2}{*}{$\begin{array}{l}\% \\
\text { inhibition }\end{array}$} \\
\hline & & Ring & Trophozoite & Schizont & & & \\
\hline \multirow[t]{5}{*}{ Negative control } & 0 & 41 & 5 & 1 & 0.76 & - & - \\
\hline & 6 & 38 & 11 & 2 & 0.84 & 0.08 & - \\
\hline & 12 & 36 & 15 & 2 & 0.86 & 0.10 & - \\
\hline & 24 & 45 & 19 & 7 & 1.14 & 0.38 & - \\
\hline & 48 & 95 & 30 & 4 & 2.06 & 1.30 & - \\
\hline \multirow[t]{5}{*}{$90 \%$ ethanolic extract of C. spectabilis DC leaf } & 0 & 41 & 5 & 1 & 0.76 & - & - \\
\hline & 6 & 38 & 10 & 1 & 0.81 & 0.05 & 37.5 \\
\hline & 12 & 34 & 11 & 5 & 0.79 & 0.03 & 70 \\
\hline & 24 & 22 & 13 & 2 & 0.59 & 0 & 100 \\
\hline & 48 & 17 & 0 & 0 & 0.28 & 0 & 100 \\
\hline
\end{tabular}

$\%$ parasitemia was obtained from total number of parasites divide to ring, trophozoite and schizont

$\%$ growth was obtained from $\%$ parasitemia an incubation time minus \% parasitemia at $0 \mathrm{~h}$

$\%$ inhibition was calculated according to the following formula: \% inhibition = ((parasitemia in negative control - parasitemia in treatment group) / parasitemia in negative control) $\times 100$

Negative control: The cultures were only added with DMSO, without any extract. The DMSO was used as negative control because DMSO was used to dissolve the extract 


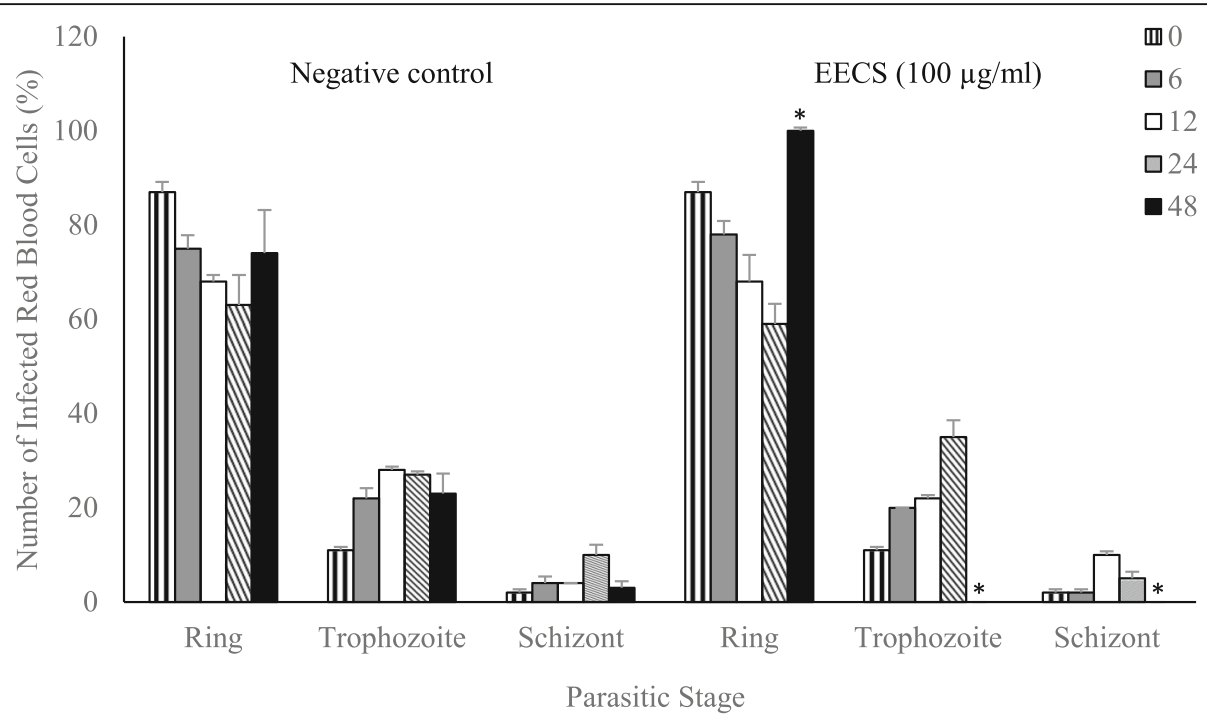

Fig. 4 Stages development of $P$. falciparum 3D7 in vitro treated with $90 \%$ ethanolic extract of C. spectabilis DC leaf at different incubation time. Parasitic morphology and the development of each stage were assessed at the beginning of incubation ( $0 \mathrm{~h})$ and at $6,12,24$, and $48 \mathrm{~h}$. The stages of parasite were classified in three groups: ring, trophozoite, and schizont. The parasitic differential count was reported as a percentage of the total red blood cells infected with those stages. Five bars in each group according to different incubation times (left to right): $0,6,12,24$, and $48 \mathrm{~h}$. EECS $=90 \%$ ethanolic extract of C. spectabilis DC leaf. ${ }^{*} p<0.05$

control which moved upward but the tests extract went to 0 . At $12-24 \mathrm{~h}$ of incubation period, parasite growth decreased but not significantly compared to negative control. Whereas at $48 \mathrm{~h}$ of incubation, parasite growth decreased significantly $(p=0.005)$ compared to negative control, with an inhibition percentage of $100 \%$ (Fig. 5).

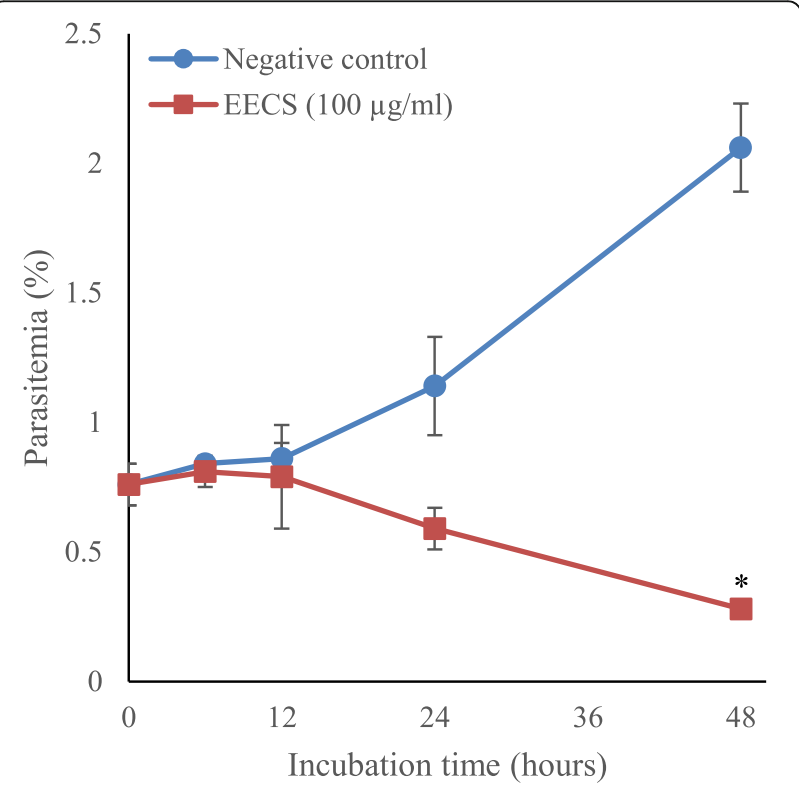

Fig. 5 Percentage of parasitemia of $90 \%$ ethanolic extract $C$. spectabilis DC leaf and control at each incubation time against $P$. falciparum $3 \mathrm{D} 7$ in vitro. $\mathrm{EECS}=90 \%$ ethanolic extract of $\mathrm{C}$. spectabilis DC leaf. ${ }^{*} p<0.05$

\section{In vivo antiplasmodial prophylactic activity test}

The results of in vivo antiplasmodial prophylactic activity test of $90 \%$ ethanolic extract of C. spectabilis DC leaf against $P$. berghei ANKA infection in mice is shown in Table 6.

The dose of extract of $800 \mathrm{mg} / \mathrm{kg}$ provided the greatest inhibitory effect $(68.61 \%)$ compared to other doses. Probit analysis resulted in $\mathrm{ED}_{50}$ value was $161.20 \mathrm{mg} / \mathrm{kg}$.

\section{In vivo antiplasmodial suppressive activity test}

Table 7 shows the results of suppressive activity tests by C. spectabilis DC leaf extract combined with artesunate. Suppressive effects produced by the three extractartesunate combinations were higher than artesunate alone. Moreover, the suppressive effects of group D (ethanolic extract of C. spectabilis DC leaf at $150 \mathrm{mg} / \mathrm{kg}$ (three times a day) on $\mathrm{D}_{0}-\mathrm{D}_{2}$ and artesunate at $36.4 \mathrm{mg} /$ $\mathrm{kg}$ on $\mathrm{D}_{2}$ ) was higher (99.18\%) than those showed by artesunate alone $(82.60 \%)$ and artesunate-amodiaquine combination (92.88\%).

\section{Heme polymerization inhibition test}

The $\mathrm{IC}_{50}$ value of the heme inhibition test by $90 \%$ ethanolic extract of C. spectabilis DC leaf was $0.375 \mathrm{mg} / \mathrm{ml}$, while chloroquine as an antimalarial standard compound was $0.682 \mathrm{mg} / \mathrm{ml}$ (Table 8 ).

\section{Discussion}

Anti-malarial activities of C. spectabilis DC leaf was conducted to extract, fraction and pure isolate. The active 
Table 6 Prophylactic effects of 90\% ethanol extract of C. spectabilis DC leaf to the growth of parasites compared with controls

\begin{tabular}{llll}
\hline Sample & Dose $(\mathbf{m g} / \mathbf{k g})$ & Parasitemia (\%) & Inhibition (\%) \\
\hline 90\% ethanolic extract of C. spectabilis DC leaf & 100 & $5.95 \pm 1.21$ & 40.14 \\
& 200 & $4.06 \pm 1.00$ & 59.16 \\
& 400 & $3.97 \pm 0.89$ & 60.06 \\
Doxycycline & 800 & $3.12 \pm 0.44$ & 68.61 \\
Na CMC & 13 & $2.63 \pm 0.88$ & 73.54 \\
\hline
\end{tabular}

$\mathrm{Na} \mathrm{CMC}$ were used as a negative control

compounds were identified by TLC-densitometry, UVVis spectrophotometry, FTIR spectroscopy, and NMR. In the ${ }^{1} \mathrm{H}-\mathrm{NMR}$ spectra, compound C.8.3.1 showed similarities to the compound (-)-7-hydroxycassine (Fig. 6) in the presence of several similar chemical shifts [26].

The greatest prophylactic inhibitory effect in vivo of $90 \%$ ethanolic extract of $C$. spectabilis DC leaf against $P$. berghei ANKA was $68.61 \%$ provided by the mice treated with $800 \mathrm{mg} / \mathrm{kg}$ of the extract. This result was lower than that of mice treated with doxycycline (73.54\%). The highest dose that can be used in mice is $1000 \mathrm{mg} / \mathrm{kg}$ of bodyweight [27].

The effect of $90 \%$ ethanolic extract of C. spectabilis DC leaf to inhibit heme detoxification process showed the $\mathrm{IC}_{50}$ value of $0.375 \mathrm{mg} / \mathrm{ml}$ which was higher than that of chloroquine as a standard antimalarial drug which was $0.682 \mathrm{mg} / \mathrm{ml}$.

The potential for $90 \%$ ethanolic extract of C. spectabilis DC leaf in the inhibition of hemozoin formation caused morphological and growth disturbances of malaria parasites due to membrane damage and disruption of the activity of several enzymes [28] as seen during the 12-h incubation period where the inhibitory activity $70 \%$ increase compared to controls. Furthermore, after $24 \mathrm{~h}$ incubation, the growth of parasites was 100\% inhibited compared to the control (Table 5).

The advantage of the combination therapy was to increase the effectiveness of extract to prevent or slow the onset of resistance to a single antimalarial drug [29]. Selection of $90 \%$ ethanolic extract of C. spectabilis DC leaf combination with artesunate referred to the basis of malaria treatment which is a standard antimalarial drug recommended by WHO [30].

The dose of $90 \%$ ethanolic extract of C. spectabilis DC leaf used was $150 \mathrm{mg} / \mathrm{kg}$ given three times [1]. Artesunate is the artemisinin derivative is a schizonticidal with fast onset of action and gametocytocidal which can reduce malaria transmission in endemic areas [31]. Artesunate at a dose of $36.4 \mathrm{mg} / \mathrm{kg}$ was converted dose from human to mouse. The three times a day of artesunate therapy was compared to single dose therapy to prevent the immediate emerging of parasites resistance to this antimalarial drug. The control used in this study was a single dose of artesunate alone at the dose of $36.4 \mathrm{mg} / \mathrm{kg}$ and amodiaquine alone at the dose of $72.8 \mathrm{mg} / \mathrm{kg}$ which were given for 3 days. As recommended by WHO that ACT administration that given for 3 days has been able to effectively inhibit the growth of parasites, beside antimalarial drug should be effective, safe, and used in a short time. The Na CMC was used as negative control since this solvent was used to dissolve the extract in this test.

The interesting result was seen in the combination therapy using three times a day of $90 \%$ ethanolic extract of C. spectabilis DC leaf at dose of $150 \mathrm{mg} / \mathrm{kg}$ for 3 days with a single dose of artesunate at the dose of $36.4 \mathrm{mg} /$ $\mathrm{kg}$ given on the third day. This combination therapy showed a higher inhibitory activity (99.18\%) compared to that of combination artesunate and amodiaquine for 3 days $(92.88 \%)$. This combination therapy may overcome

Table 7 Suppressive effect of $90 \%$ ethanolic extract of C. spectabilis DC leaf combined with artesunate to the growth of parasite in mice

\begin{tabular}{|c|c|c|c|}
\hline \multirow[t]{2}{*}{ Treatment } & \multicolumn{2}{|c|}{ Parasitemia count } & \multirow{2}{*}{$\begin{array}{l}\text { Suppression } \\
\text { (\%) }\end{array}$} \\
\hline & $D_{0}$ & $\mathrm{D}_{3}$ & \\
\hline $\mathrm{Na} C M C$ & $1.84 \pm 0.59$ & $9.14 \pm 2.38$ & - \\
\hline C. spectabilis $\mathrm{DC}+$ Artesunate $\left(\mathrm{D}_{0}-\mathrm{D}_{2}\right)$ & $2.01 \pm 0.64$ & $3.11 \pm 1.30$ & 84.93 \\
\hline C. spectabilis $\mathrm{DC}\left(\mathrm{D}_{0}-\mathrm{D}_{2}\right)+$ Artesunate $\left(\mathrm{D}_{0}\right)$ & $2.92 \pm 0.73$ & $3.40 \pm 1.21$ & 90.14 \\
\hline C. spectabilis $D C\left(D_{0}-D_{2}\right)+$ Artesunate $\left(D_{2}\right)$ & $2.22 \pm 1.14$ & $2.08 \pm 1.28$ & 99.18 \\
\hline Artesunate & $2.27 \pm 0.76$ & $3.40 \pm 1.24$ & 82.60 \\
\hline Amodiaquine + Artesunate & $1.62 \pm 0.74$ & $1.97 \pm 0.68$ & 92.88 \\
\hline
\end{tabular}

$\mathrm{Na} \mathrm{CMC}$ were used as a negative control 
Table 8 Inhibitory effect of 90\% ethanolic extract of C. spectabilis DC leaf on the heme polymerization compared with controls

\begin{tabular}{|c|c|c|c|c|}
\hline Samples & Concentration $(\mathrm{mg} / \mathrm{ml})$ & Level of hematin (mM) & Inhibition (\%) & $\mathrm{IC}_{50}(\mathrm{mg} / \mathrm{ml})$ \\
\hline \multirow[t]{6}{*}{$90 \%$ ethanolic extract of C. spectabilis DC leaf } & 2 & $67.32 \pm 4.49$ & $76.49 \pm 1.57$ & 0.375 \\
\hline & 1 & $85.34 \pm 1.42$ & $70.20 \pm 0.50$ & \\
\hline & 0.5 & $118.49 \pm 2.92$ & $58.62 \pm 1.02$ & \\
\hline & 0.25 & $186.37 \pm 6.55$ & $34.91 \pm 2.29$ & \\
\hline & 0.1 & $223.85 \pm 4.35$ & $21.82 \pm 1.52$ & \\
\hline & 0.01 & $252.00 \pm 1.85$ & $11.99 \pm 0.64$ & \\
\hline \multirow[t]{6}{*}{ Chloroquine diphosphate } & 2 & $99.80 \pm 2.50$ & $65.15 \pm 0.97$ & 0.682 \\
\hline & 1 & $125.65 \pm 4.03$ & $56.12 \pm 1.41$ & \\
\hline & 0.5 & $158.00 \pm 4.63$ & $44.82 \pm 1.62$ & \\
\hline & 0.25 & $186.78 \pm 3.95$ & $34.76 \pm 1.38$ & \\
\hline & 0.1 & $207.05 \pm 1.96$ & $27.69 \pm 0.68$ & \\
\hline & 0.01 & $229.53 \pm 9.26$ & $19.84 \pm 3.24$ & \\
\hline DMSO & - & $286.33 \pm 2.92$ & - & - \\
\hline
\end{tabular}

DMSO were used as a negative control

the resistance of parasites to artesunate because shorten the duration of treatment period. Thus, the combination of 90\% ethanolic extract of C. spectabilis DC leaf with artesunate can be expected as a new antimalarial combination drug which may replace the artesunate-amodiaquine combination drug that has been used so far. The mixture of artesunate-amodiaquine caused the drug preparations will become unstable [32]. Concurrent drug administration in a separate formula have the disadvantage of reducing patient compliance to take the drug, but the combination therapy can shorten the duration of treatment therapy [30].

\section{Conclusion}

The results show 90\% ethanolic extract of C.spectabilis DC leaf has a very good antiplasmodial activities both in vitro and in vivo study and revealed potentiated effect in combination with artesunate. The $90 \%$ ethanol extract of C. spectabilis DC leaf also found to be active in inhibiting the heme detoxification process. Compound of (-)-7-hydroxycassine may play as important role in antimalarial activities. Therefore, this plant can be potentially used as a new source for the development of new plant-based antimalarial agent.

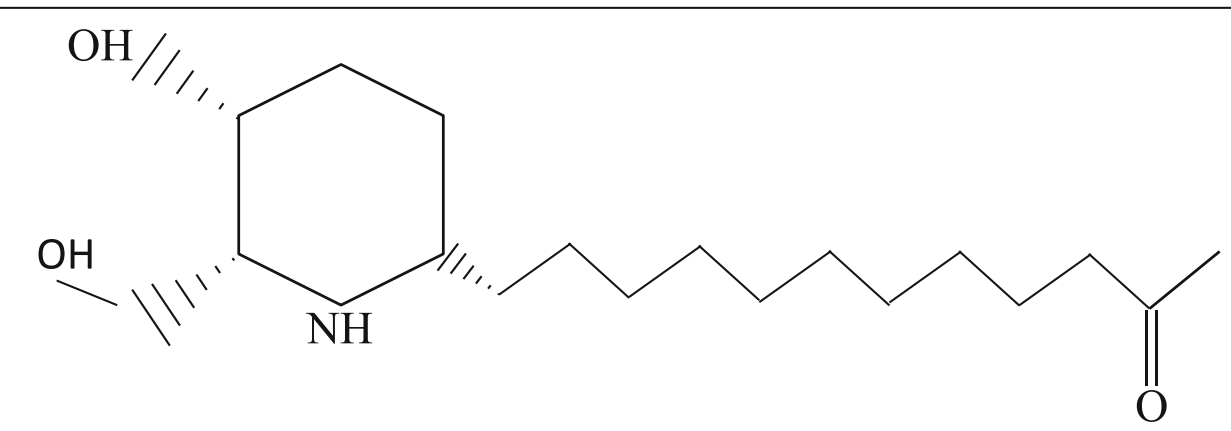

Fig. 6 Molecular structure of (-)-7-hydroxycassine 


\section{Abbreviations}

ACT: Artemisinin-based combination therapy; $\mathrm{CHCl}_{3}$ : Chloroform; DMSO: Dimethyl sulfoxide; ED 50 : Median effective dose; EECS: Ethanolic extract of Cassia spectabilis DC leaf; ELISA: Enzyme-linked immunosorbent assay; EtOAc: Ethyl acetate; Fe(II)PPIX: Ferrous-protoporphyrin IX; FTIR: Fouriertransform infrared; HEPES: N-2-hydroxyethylpiperazine-N-ethanesulfonic acid; $I_{50}$ : The half maximal inhibitory concentration; IR: Infrared; $\mathrm{MeOH}$ : Methanol; $\mathrm{Na} \mathrm{CMC}$ : Sodium carboxymethylcellulose; $\mathrm{NaHCO}_{3}$ : Sodium bicarbonate; $\mathrm{NaOH}$ : Sodium hydroxide; NMR: Nuclear magnetic resonance; PBS: Phosphate buffered saline; PTLC: Preparative thin-layer chromatography; RPMI: Roswell Park Memorial Institute; TLC: Thin-layer chromatography; UV-Vis: Ultravioletvisible; WHO: World health organization

\section{Acknowledgments}

We would like to thank The Ministry of Research, Technology, and Higher Education of the Republic of Indonesia [Kementerian Riset, Teknologi, dan Pendidikan Tinggi Republik Indonesia, RISTEKDIKTI RI] scheme for financial support.

\section{Authors' contributions}

Conceived and designed the experiment: WE, DRB, HA and TSW. Analyzed the data: WE and HA. Contributed reagents/materials/analysis tools: WE. Wrote the manuscript: WE, DRB and TSW. All authors read and approved the final manuscript.

\section{Funding}

This research was granted by The Ministry of Research, Technology, and Higher Education of the Republic of Indonesia with grant number 586/UN3/ 2017. The funders had no role in the study design and analysis.

\section{Availability of data and materials}

The all data used to support the findings of this study are available from the corresponding authors upon request.

\section{Ethics approval and consent to participate}

This work was approved by Animal care and Use Committee, Airlangga University, No 2.KE.181.10.2018.

\section{Consent for publication}

Not applicable.

\section{Competing interests}

The authors declare that they have no competing of interest.

\section{Author details}

'Department of Pharmacognosy and Phytochemistry, Faculty of Pharmacy, Universitas Airlangga, Campus C, Mulyorejo Street, Surabaya 60115, Indonesia. ${ }^{2}$ Department of Medical Parasitology, Faculty of Medicine, Universitas Airlangga, Campus A, Surabaya 60132, Indonesia.

Received: 2 March 2020 Accepted: 2 February 2021

Published online: 19 February 2021

\section{References}

1. Ekasari W, Wahyuni TS, Arwaty H, Putri NT. Determination of effective dose antimalarial from Cassia spectabilis leaf ethanol extract in Plasmodium berghei-infected mice. Afr J Infect Dis. 2018;12(1 Suppl):110-5.

2. Morita H, Oshimi S, Hirasawa Y, Koyama K, Honda T, Ekasari W, et al. Cassiarins a and B, novel antiplasmodial alkaloids from Cassia siamea. Org Lett. 2007:9(18):3691-3.

3. Ekasari W, Widyawaruyanti A, Zaini NC. Antimalarial activity of cassiarin a from the leaves of Cassia siamea. Heterocycles. 2009;78(7):1831-6.

4. Elyazar IRF, Hay SI, Baird JK. Malaria distribution, prevalence, drug resistance and control in Indonesia. Adv Parasitol. 2011;74:41-175.

5. Tan KR, Magill AJ, Parise ME, Arguin PM. Doxycycline for malaria chemoprophylaxis and treatment: report from the CDC expert meeting on malaria chemoprophylaxis. Am J Trop Med Hyg. 2011;84(4):517-31.

6. Chugh M, Sundararaman V, Kumar S, Reddy VS, Siddiqui WA, Stuart KD, et al. Protein complex directs hemoglobin-to-hemozoin formation in Plasmodium falciparum. Proc Natl Acad Sci U S A. 2013;110(14):5392-7.
7. Slater AF, Cerami A. Inhibition by chloroquine of a novel haem polymerase enzyme activity in malaria trophozoites. Nature. 1992;355(6356):167-9.

8. Slater AF, Swiggard WJ, Orton BR, Flitter WD, Goldberg DE, Cerami A, et al. An iron-carboxylate bond links the heme units of malaria pigment. Proc Natl Acad Sci U S A. 1991;88(2):325-9.

9. Bohle DS, Conklin BJ, Cox D, Madsen SK, Paulson S, Stephens PW, et al. Structural and spectroscopic studies of $\beta$-hematin (the heme coordination polymer in malaria pigment). Inorganic and organometallic polymers II. ACS Symposium Series. Am Chem Soc. 1994;572:497-515.

10. Bohle S, Dinnebier R, Madsen S, Stephens P, Bohle SD, Dinnebier RE, Madsen SK, Stephens PW. Characterization of the products of the heme detoxification pathway in malarial late trophozoites by X-ray diffraction. J Biol Chem. 1997:272:713-6.

11. Pagola S, Stephens PW, Bohle DS, Kosar AD, Madsen SK. The structure of malaria pigment beta-haematin. Nature. 2000;404(6775):307-10.

12. Fong KY, Wright DW. Hemozoin and antimalarial drug discovery. Future Med Chem. 2013:5(12):1437-50

13. Olafson KN, Ketchum MA, Rimer JD, Vekilov PG. Mechanisms of hematin crystallization and inhibition by the antimalarial drug chloroquine. Proc Natl Acad Sci U S A. 2015;1 12(16):4946-51.

14. Kremsner PG, Krishna S. Antimalarial combinations. Lancet. 2004:364(9430): 285-94.

15. Nandakumar DN, Nagaraj VA, Vathsala PG, Rangarajan P, Padmanaban G Curcumin-artemisinin combination therapy for malaria. Antimicrob Agents Chemother. 2006;50(5):1859-60.

16. WHO. Artemisinin resistance and artemisinin-based combination therapy efficacy: status report, vol. 2018. Geneva: World Health Organization; 2018. Contract No.: WHO/CDS/GMP/2018.18

17. Alvarez G, Tobón A, Piñeros J-G, Ríos A, Blair S. Dynamics of Plasmodium falciparum parasitemia regarding combined treatment regimens for acute uncomplicated malaria, Antioquia, Colombia. Am J Trop Med Hyg. 2010; 83(1):90-6.

18. Trager W, Jensen JB. Human malaria parasites in continuous culture. 1976. J Parasitol. 2005;91(3):484-6.

19. Carbone L, Carbone ET, Yi EM, Bauer DB, Lindstrom KA, Parker JM, et al. Assessing cervical dislocation as a humane euthanasia method in mice. J Am Assoc Lab Anim Sci. 2012;51(3):352-6.

20. Ekasari W, Widya Pratiwi D, Amanda Z, Suciati WA, Arwati H. Various parts of Helianthus annuus plants as new sources of antimalarial drugs. Evid Based Complement Alternat Med. 2019;2019:7390385.

21. Peters W. The chemotherapy of rodent malaria, XXII. The value of drugresistant strains of $P$. berghei in screening for blood schizontocidal activity. Ann Trop Med Parasitol. 1975;69(2):155-71.

22. Lemeshow S, Hosmer DW, Klar J, Lwanga SK, World HO. Adequacy of sample size in health studies / Stanley Lemeshow. Chichester: Wiley; 1990.

23. Basilico N, Pagani E, Monti D, Olliaro P, Taramelli D. A microtitre-based method for measuring the haem polymerization inhibitory activity (HPIA) of antimalarial drugs. J Antimicrob Chemother. 1998;42(1):55-60.

24. Rieckmann KH, Campbell GH, Sax LJ, Mrema JE. Drug sensitivity of Plasmodium falciparum. An in-vitro microtechnique. Lancet. 1978;1(8054):22-3.

25. Gessler MC, Nkunya MH, Mwasumbi LB, Heinrich M, Tanner M. Screening Tanzanian medicinal plants for antimalarial activity. Acta Trop. 1994;56(1): 65-77.

26. Viegas Junior C, Pivatto M, Ad R, Hamerski L, DHS S, VdS B. (-)-7hydroxycassine: a new 2,6-dialkylpiperidin-3-ol alkaloid and other constituents isolated from flowers and fruits of Senna spectabilis (Fabaceae). J Braz Chem Soc. 2013;24:230-5.

27. Munoz V, Sauvain M, Bourdy G, Callapa J, Rojas I, Vargas L, et al. The search for natural bioactive compounds through a multidisciplinary approach in Bolivia. Part II. Antimalarial activity of some plants used by Mosetene indians. J Ethnopharmacol. 2000;69(2):139-55.

28. Tekwani BL, Walker LA. Targeting the hemozoin synthesis pathway for new antimalarial drug discovery: technologies for in vitro beta-hematin formation assay. Comb Chem High Throughput Screen. 2005:8(1):63-79.

29. Somsak V, Borkaew P, Klubsri C, Dondee K, Bootprom P, Saiphet B. Antimalarial properties of aqueous crude extracts of Gynostemma pentaphyllum and Moringa oleifera leaves in combination with artesunate in Plasmodium berghei-infected mice. J Trop Med. 2016:2016:8031392.

30. WHO. Guidelines Approved by the Guidelines Review Committee. In: rd, editor. Guidelines for the Treatment of Malaria, vol. 2015. Geneva: World Health Organization. Copyright (c) World Health Organization; 2015. 
31. Barradell LB, Fitton A. Artesunate. A review of its pharmacology and therapeutic efficacy in the treatment of malaria. Drugs. 1995;50(4):714-41.

32. Zaman V, Keong LA. Handbook of Medical Parasitology: Churchill

Livingstone; 1990

\section{Publisher's Note}

Springer Nature remains neutral with regard to jurisdictional claims in published maps and institutional affiliations.

Ready to submit your research? Choose BMC and benefit from:

- fast, convenient online submission

- thorough peer review by experienced researchers in your field

- rapid publication on acceptance

- support for research data, including large and complex data types

- gold Open Access which fosters wider collaboration and increased citations

- maximum visibility for your research: over $100 \mathrm{M}$ website views per year

At BMC, research is always in progress.

Learn more biomedcentral.com/submissions 